\title{
Occurrence of southern right whales (Eubalaena australis) along southeastern Brazil
}

\author{
Marcos César de Oliveira Santos*, Salvatore Siciliano ${ }^{+}$, Shirley Pacheco de Souza ${ }^{\dagger}$, Jose Luis Altmayer \\ PIZZORNO
}

Contacte-mail: marcosos@usp.br

\begin{abstract}
This paper reports on the occurrence of southern right whales (Eubalaena australis) in southeastern Brazilian waters $\left(18^{\circ} \mathrm{S}-25^{\circ} \mathrm{S}\right)$, with evidence of their use of the region as an important calving area. Only in recent years have right whale sightings and strandings been reported regularly within the surveyed area. Of 71 distinct sightings reported since 1936, $39(54.9 \%)$ were mother-calf pairs observed close to the shore. Most of these sightings $(91.5 \%)$ were reported from early July to late October. Eight confirmed strandings of this species were observed within the surveyed area, six of which were between July and October. Stranded calves represented $62.5 \%$ of these records. Two calves showed evidence of incidental capture. The increasing number of sightings, and recent reports of stranded calves and one adult female could be indicative of an increase in cetacean research efforts in the region. However, it also suggests use of the southeastern Brazilian coast as an important right whale calving area.
\end{abstract}

KEYWORDS: SOUTHERN RIGHT WHALE; SOUTH ATLANTIC; INCIDENTAL SIGHTINGS; STRANDINGS

\section{INTRODUCTION}

Southern right whales (Eubalaena australis) have typically been observed in every ocean from about $20^{\circ} \mathrm{S}$ to $50^{\circ} \mathrm{S}$ (Cummings, 1985). Along the western South Atlantic, wintering southern right whales have been reported in Argentina (Omura, 1986; Whitehead et al., 1986; Payne et al., 1990), Uruguay (Townsend, 1935) and southern, southeastern and northeastern Brazilian coastal waters (Carvalho, 1938; Castello and Pinedo, 1979; Câmara and Palazzo Jr., 1986; Secchi, 1990; Simões-Lopes et al., 1992; Greig et al., 1994; Lodi et al., 1996).

Historical documents provide some information on this species' distribution and exploitation along the Brazilian coast (e.g. Townsend, 1935; Ellis, 1969). Despite being protected by an international agreement since 1935, direct captures occurred along the coast of Santa Catarina state $\left(27^{\circ} \mathrm{S}\right)$ until 1973 (Palazzo and Carter, 1983).

Little is known about this species in Brazilian waters. Systematic surveys to study right whales are lacking in most parts of their range. Most of the available data were obtained through occasional sightings and strandings along the southern Brazilian coast $\left(25^{\circ} \mathrm{S}-34^{\circ} \mathrm{S}\right)$. In the last 20 years, right whales have occasionally been reported in southeastern Brazil $\left(18^{\circ} \mathrm{S}-25^{\circ} \mathrm{S}\right)$.

This paper reviews the occurrence of southern right whales along the southeastern Brazilian coast in recent decades and presents evidence that this region is an important calving area for right whales.

\section{MATERIAL AND METHODS}

The study area in southeastern Brazil includes São Paulo (SP), Rio de Janeiro (RJ) and Espírito Santo (ES) states (Fig. $1)$. This area is characterised by a great number of shallow bays and inlets with calm waters along $\mathrm{ca} 1,940 \mathrm{~km}$ of coastline (Diretoria de Hidrografia e Navegação, 1966).

Data have been compiled from scientific literature (Carvalho, 1938; Sawaya, 1938; Ellis, 1969; Moreira et al., 1994; Capistrano et al., 1996; Lodi et al., 1996; Zampirolli et al., 1998; Azevedo et al., 1999; Di Beneditto and Ramos, 1999), media files (Folha de São Paulo and A Tribuna de Santos) and visits to museums and other institutions (Museu de Zoologia da Universidade de São Paulo, Museu Nacional do Rio de Janeiro, Museu do Mar de Santos and Museu do Instituto de Pesca de Santos) that keep osteological material and/or photographs, to ensure species identification. Unpublished data from occasional sightings and dedicated observation surveys have also been included. Dedicated surveys have been carried out in Atafona (RJ) since 1993, in Campos Basin (RJ) since August 1998 and in Arraial do Cabo (RJ) since July 1999.

A 'sighting' refers to an observation of a right whale individual or group at a known position within the surveyed area.

\section{RESULTS}

\section{Sightings}

Right whale sightings presented here cover the period between 1936 and 1999. Some of these sightings may be duplicates. The compiled data comprises 71 sightings ( $n=135$ whales) made in the coastal waters of São Paulo $(n=17)$, Rio de Janeiro $(n=51)$ and Espírito Santo $(n=3)$. The majority of the reported sightings (91.5\%) were concentrated in the four-month period between July and October (Table 1). Since 1981, right whale sightings have been reported within the study area in every year except 1987, 1990, 1994 and 1997. Mother-calf pair observations represent $57.1 \%$ of all sightings.

\footnotetext{
* Departamento de Ecologia Geral, Instituto de Biociências, Universidade de São Paulo, Rua do Matão 321, Cidade Universitária, São Paulo, SP 05508-900 Brazil.

+ Universidade Federal do Rio de Janeiro, Departamento de Vertebrados/Zoologia Museu, São Cristóvão, Rio de Janeiro, RJ $20940-040$ Brazil.

† FUNDAMAR, Rua Antônio Cândido 214, São Sebastião, SP 11600-000 Brazil.

* Av. Maracanã 772 apto 307, Rio de Janeiro, RJ 20550-001 Brazil.
} 


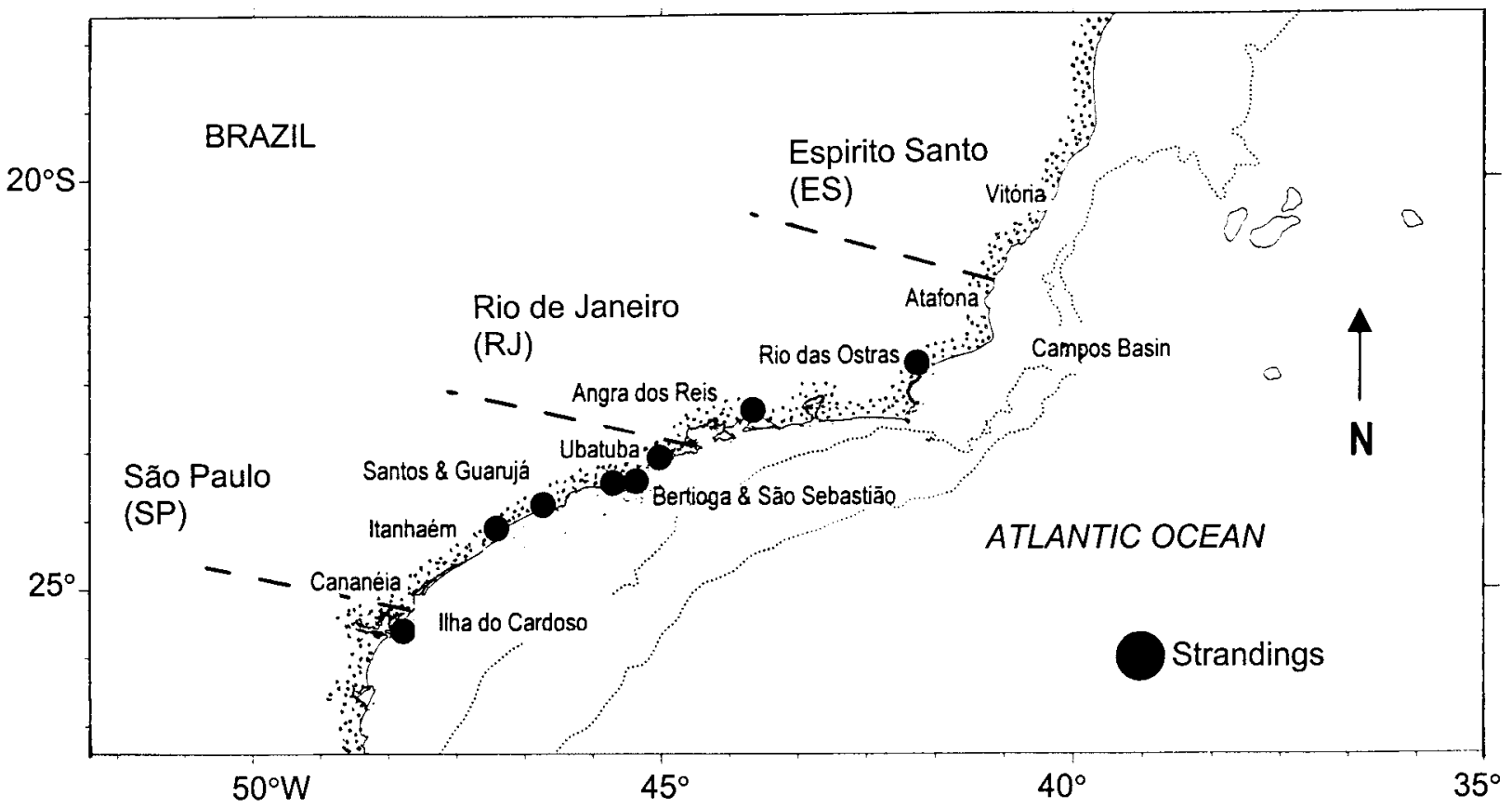

Fig. 1. Brazilian southeastern coast in detail showing the exact points where southern right whales strandings were reported from 1936-1998. A total of 71 confirmed sightings have been reported since 1936 from Cananéia (SP) to Vitória (ES). The majority of sightings were observed in coastal waters between Ubatuba (SP) and Atafona (RJ).

Table 1

Monthly sightings of southern right whales, Eubalaena australis, in each state along the southeastern Brazilian coast. Sightings $(n=71)$ occurred between 1938 and 1999 .

\begin{tabular}{lcrrrrrrr}
\hline State & Jun. & Jul. & Aug. & Sep. & Oct. & Nov. & Dec. & Total \\
\hline São Paulo & - & 6 & 3 & 1 & 7 & - & - & 17 \\
Rio de Janeiro & 1 & 9 & 22 & 9 & 5 & 4 & 1 & 51 \\
Espírito Santo & - & - & 2 & - & 1 & - & - & 3 \\
Total & 1 & 15 & 27 & 10 & 13 & 4 & 1 & 71 \\
\hline
\end{tabular}

\section{Strandings}

Only eight strandings have been reported from the southeastern Brazilian coast: six in São Paulo and two in Rio de Janeiro (Table 2). Five of the stranded right whales were calves, one was a juvenile (Fig. 2) and the other two were adults. The two stranded whales examined from Rio de Janeiro showed evidence of net entrapment; however, for the other specimens the cause of death remains unknown. Umbilical cord remains were observed with a dead calf stranded at São Sebastião.

\section{DISCUSSION AND RECOMMENDATIONS}

The relatively high percentage of mother-calf pair sightings $(54.9 \%)$ and strandings of calves (including one dead calf with umbilical cord remains), provide evidence of the possible use of southeastern Brazilian coastal waters by right whales as a calving area. Ellis (1969) described whales, mainly mother-calf pairs, using shallow bays and inlets during rough sea conditions. Females with calves may come closer to the shore in higher proportions than single individuals or multiple adult groups. If so, this would mean that mother-calf pairs might be over-represented in our sample. Sightings effort must be expanded to include offshore waters to determine if this is the case.

Historical documents and published literature reveal that right whales were found along the southeastern Brazilian coast in the past. Depletion of the species is known to have
Table 2

Southern right whales, Eubalaena australis, strandings $(n-8)$ reported along the southeastern Brazilian coast from 1936 until 2000. L - Body length.

\begin{tabular}{|c|c|c|c|c|}
\hline Date & Location & $\mathrm{L}(\mathrm{cm})$ & Sex & Source \\
\hline Oct. 1936 & $\begin{array}{l}\text { Guarujá, SP } \\
\left(23^{\circ} 59^{\prime} \mathrm{S}, 46^{\circ} 15^{\prime} \mathrm{W}\right)\end{array}$ & $\mathrm{calf} / \mathrm{L}$ ? & & Sawaya (1938) \\
\hline 27 Jan. 1955 & $\begin{array}{l}\text { Itanhaém, SP } \\
\left(24^{\circ} 10^{\prime} \mathrm{S}, 46^{\circ} 45^{\prime} \mathrm{W}\right)\end{array}$ & ca 800 & & Present study \\
\hline 19 Sep. 1984 & $\begin{array}{l}\text { Bertioga, SP } \\
\left(23^{\circ} 50^{\prime} \mathrm{S}, 46^{\circ} 08^{\prime} \mathrm{W}\right)\end{array}$ & ca 1,300 & & Lodi et al. (1996) \\
\hline 17 Aug. 1995 & $\begin{array}{l}\text { Angra dos Reis, RJ } \\
\left(23^{\circ} 10^{\prime} \mathrm{S}, 44^{\circ} 20^{\prime} \mathrm{W}\right)\end{array}$ & ca 590 & $\mathrm{~F}$ & $\begin{array}{l}\text { Capistrano et al. } \\
\text { (1996) }\end{array}$ \\
\hline 19 Sep. 1995 & $\begin{array}{l}\text { Ubatuba, SP } \\
\left(23^{\circ} 10^{\prime} \mathrm{S}, 45^{\circ} 04^{\prime} \mathrm{W}\right)\end{array}$ & ca 400 & $\mathrm{M}$ & Present study \\
\hline $6 \mathrm{Jul} .1996$ & $\begin{array}{l}\text { São Sebastião, SP } \\
\left(23^{\circ} 49^{\prime} \mathrm{S}, 45^{\circ} 24^{\prime} \mathrm{W}\right)\end{array}$ & 420 & $\mathrm{M}$ & Present study \\
\hline 8 Sep. 1998 & $\begin{array}{l}\text { Rio das Ostras, RJ } \\
\left(22^{\circ} 26^{\prime} \mathrm{S}, 42^{\circ} 49^{\prime} \mathrm{W}\right)\end{array}$ & 1,740 & $\mathrm{~F}$ & $\begin{array}{l}\text { Azevedo et al. } \\
\text { (1999) }\end{array}$ \\
\hline 14 Jan. 2000 & $\begin{array}{l}\text { Ilha do Cardoso, SP } \\
\left(25^{\circ} 00^{\prime} \mathrm{S}, 48^{\circ} 55^{\prime} \mathrm{W}\right)\end{array}$ & 750 & & Present study \\
\hline
\end{tabular}

occurred in Brazilian waters over the last four centuries (IWC, 2001). Scientific studies of right whales in Brazil only began in the 1980s and sighting effort in coastal waters has not been uniform. Dedicated surveys have only been conducted in Santa Catarina in the last decade and in Rio de Janeiro in recent years. Data collected since then suggest that the population is increasing (Pinedo, 1984; Câmara and Palazzo Jr., 1986). The data presented here suggest that right whales are reoccupying areas along the southeastern Brazilian coast which they inhabited prior to their exploitation. It is clear that interpretation of possible trends is confounded by the increase in research effort. Further systematic research is required before firm conclusions on movement, distribution and population parameters can be drawn.

As in other areas of the world, right whales face several potential threats along the southeastern Brazilian coast. Gillnets are used in coastal areas and may be an important cause of mortality, as suggested by some of the strandings 


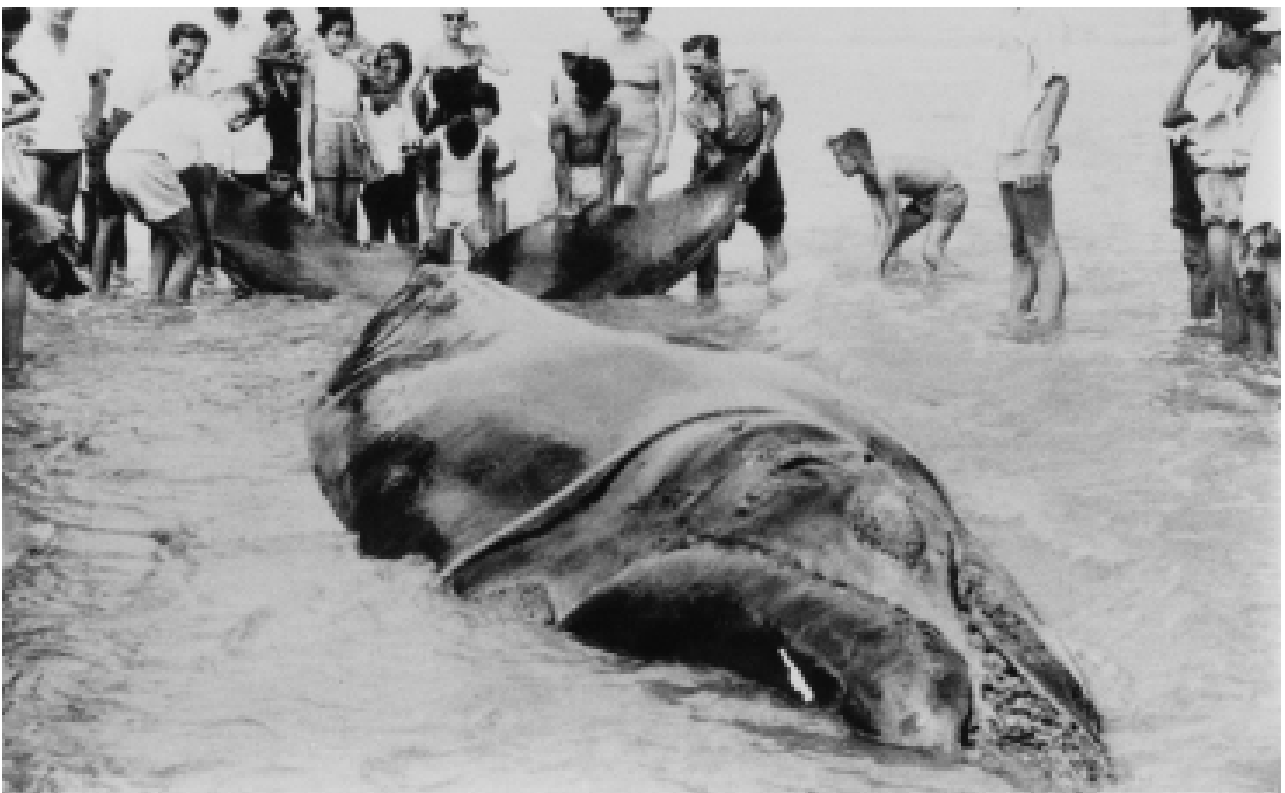

Fig. 2. A juvenile southern right whale stranded at Itanhaém ( $24^{\circ} 10^{\prime}$ S, $46^{\circ} 45^{\prime}$ S $)$, São Paulo, on 27 January 1955. (Folha de São Paulo Files).

and reports by Capistrano et al. (1996) and Lodi et al. (1996). In addition, there are several major ports (e.g. Santos, São Sebastião, Angra dos Reis, Rio de Janeiro and Vitória) within this area and vessel traffic is intense. Thus, as the right whale population grows and reoccupies its historic range, collisions with ships (and incidental catches) may increase and threaten recovery. A further potential threat arises out of uncontrolled approaches by bathers, divers and whalewatching vessels. These concerns reinforce the need for adequate educational programmes in southeastern Brazil, directed towards fishermen, tourists and public institutions such as lifeguard offices and environmental organisations.

\section{ACKNOWLEDGMENTS}

We are grateful to the volunteers who helped us in gathering as much information as possible on right whales within the surveyed area. Special thanks go to Eduardo Toscano (Projeto Boto-Cinza), André Rossi (FUNDAMAR), Elias André (Prefeitura Municipal de São Sebastião), Cláudio Tiago (CEBIMar-USP), Antônio Carlos Varallo and Mirella (Polináutica de Ubatuba), Raimundo Rosa (A Tribuna de Santos), Alexandre Simonelli and Salim Buriham (Folha de São Paulo), Émerson Zampirolli (CEEMAM), Ana Paula Di Beneditto and Renata Ramos (Universidade Estadual Norte Fluminense). David Seargeant, Alexandre Zerbini, Eduardo Secchi and Greg Donovan provided useful comments to improve this manuscript.

\section{REFERENCES}

Azevedo, A. de F., Laílson-Brito Jr., J., Cunha, H.A., Pinheiro, K.J., Carvalho, O. and Bastos, M. 1999. New records of the southern right whale (Eubalaena australis) along the coast of Rio de Janeiro State, Brazil. In: 13th Biennial Conference on the Biology of Marine Mammals, Maui, 1999, p.9. [Abstract].

Câmara, I.G. and Palazzo Jr., J.T. 1986. Novas informações sobre a presença de Eubalaena australis no sul do Brasil. In: $1^{\text {a }}$ Reunión de Trabajo de Expertos en Mamíferos Acuáticos de América del Sur, Buenos Aires, 1984. Actas, p.35-41. [In Portuguese].

Capistrano, L., Siciliano, S., Helbourne, K. and de Paula, M.I. 1996. Um filhote de baleia-franca-austral (Eubalaena australis) coletado no litoral do Rio de Janeiro, Brasil. In: XXI Congresso Brasileiro de Zoologia, Porto Alegre, 1996. Resumos. p.250. [In Portuguese].

Carvalho, J.de P. 1938. Sobre os balaenopterídeos que frequentam a costa paulista. A Voz do Mar, 161, anno XVII, pp.181-184. [In Portuguese].

Castello, H.P. and Pinedo, M.C. 1979. Southern right whales (Eubalaena australis) along the southern Brazilian coast. J. Mammal. 60(2):429-30.

Cummings, W.C. 1985. Right whales - Eubalaena glacialis (Müller, 1776) and Eubalaena australis (Desmoulins, 1822). pp. 275-304. In: S.H. Ridgway and R. Harrison (eds.) Handbook of Marine Mammals. Vol. 3. The Sirenians and Baleen Whales. Academic Press, London and Orlando. Xviii+362pp.

Di Beneditto, A.P. and Ramos, R. 1999. Avistagens de cetáceos na costa norte do Rio de Janeiro, sudeste do Brasil (1993-98). In: VIII Congreso Latinoamericano sobre Ciencias del Mar, Trujillo, Peru, 1999. Resumenes ampliados, p.269-270. [In Portuguese].

Diretoria de Hidrografia e Navegação. 1966. Marinha do Brasil, Carta Náutica $n^{\circ}$ 80, Rio de Janeiro, a Santa Catarina, $3^{\mathrm{a}}$ Edição. [In Portuguese].

Ellis. 1969. A Baleia no Brasil Colonial. Edições Melhoramentos, Editora da Universidade de São Paulo, Sao Paulo, Brasil. 235pp. [In Portuguese].

Greig, A.B., Zerbini, E.R., Secchi, E.L. and Dalla Rosa, L. 1994 Encalhe de neonatos de baleia franca, Eubalaena australis, no litoral sul do Rio Grande do Sul - Brasil. VI Reunião de Trabalho de Especialistas em Mamíferos Aquáticos da América do Sul, Florianópolis, 1994. Resumos, p.69. [In Portuguese].

International Whaling Commission. 2001. Report of the Workshop on the Comprehensive Assessment of Right Whales: A worldwide comparison. J. Cetacean Res. Manage. (special issue) 2:1-60.

Lodi, L., Siciliano, S. and Bellini, C. 1996. Ocorrências e conservação de baleias-francas-do-sul, Eubalaena australis, no litoral do Brasil. Pap. Avulsos de Zool. (São Paulo) 39(17):307-328. [In Portuguese].

Moreira, L.M de P., Siciliano, S and Alves, A. 1994. Registros de cetáceos para o litoral do Espírito Santo, Brasil 1992-1994. In: $6^{\text {a }}$ Reunião de Especialistas em Mamíferos Aquáticos da América do Sul, Florianópolis, 1994. Resumos, p.116. [In Portuguese].

Omura, H. 1986. History of right whale catches in the waters around Japan. Rep. int. Whal. Commn (special issue) 10:35-41.

Palazzo, J.T., Jr. and Carter, L.A. 1983. A caça de baleias no Brasil. AGAPAN, Porto Alegre, 25pp. [In Portuguese].

Payne, R., Rowntree, V., Perkins, J.S., Cooke, J.G. and Lankester, K. 1990. Population size, trends and reproductive parameters of right whales (Eubalaena australis) off Peninsula Valdes, Argentina. Rep. int. Whal. Commn (special issue) 12:271-8.

Pinedo, M.C. 1984. Ocorrência de Eubalaena australis no litoral do Rio Grande do Sul, com observações de cópula. In: $1^{\text {a }}$ Reunión de Expertos en Mamíferos Acuáticos de América de Sur, Buenos Aires, 1984. Resúmenes, p.34. [In Portuguese]. 
Sawaya, P. 1938. Sobre o 'Piolho da Baleia'. Bol. Fac. Filos. Cienc. Let. Univ. São Paulo Ser. Zool. 2:197-248. [In Portuguese].

Secchi, E.R. 1990. Informações inéditas sobre a presença de Eubalaena australis na costa sul do Rio Grande do Sul - Brasil. In: $3^{\text {a }}$ Reunión de Trabajo de Especialistas en Mamíferos Acuáticos de América del Sur, Valdivia, Chile, 1990. Resúmenes, p.58. [In Portuguese].

Simões-Lopes, P., Palazzo Jr, J.T., Both, M.C. and Ximénez, A. 1992. Identificação, movimentos e aspectos biológicos da baleiafranca-austral (Eubalaena australis) na costa sul do Brasil. In: $3^{a}$ Reunión de Trabajo de Expertos en Mamíferos Acuáticos de América del Sur, Montevideo, 1988. Anales, p.62-65. [In Portuguese].
Townsend, C.H. 1935. The distribution of certain whales as shown by logbook records of American whaleships. Zoologica (NY) 19(1-2):1-50+6 maps.

Whitehead, H., Payne, R. and Payne, M. 1986. Population estimate for the right whales off Peninsula Valdes, Argentina, 1971-1976. Rep. int. Whal. Commn (special issue) 10:169-71.

Zampirolli, E., Vincente, A.F.C., Alvarenga, F.S. and Pereira, M.A. 1998. Novas informações sobre registros de cetáceos para a região da Baixada Santista, São Paulo - Brasil. In: VII Reunião de Trabalho de Especialistas em Mamíferos Aquáticos da América do Sul, Olinda, Pernambuco, 1998. Resumos, p.228. [In Portuguese]. 